\title{
DAMPAK YOGA KEHAMILAN TERHADAP JENIS PERSALINAN
}

\author{
The Impact of yoga during pregnancy of childbirth \\ Dheska Arthyka Palifiana ${ }^{1}$, Nur Khasanah² \\ Universitas Respati Yogyakarta \\ (dheska87@gmail.com, nurkhasanahury@gmail.com )
}

\begin{abstract}
ABSTRAK
Latar Belakang: Persalinan normal merupakan proses keluarnya bayi dari jalan lahir secara spontan dalam waktu 24 jam tanpa menimbulkan kerusakan pada ibu mauun bayi. Tidak semua ibu dapat bersalin secara normal sehingga harus dikarenakan adanya penyulit pada saat persalinan sehingga persalinan berlangsung dengan bantuan berupa vakum ekstrasi maupun section sesarea (sc). Di Indonesia angka kejadian sc terus meningkat setiap tahunnya dari tahun 1991 sampai 2007 yaitu 1,3 - 6,8 \%. Penyebab peningkatan persalinan sc adalah adanya indikasi medis dan non medis. Salah satu upaya untuk menurunkan angka kejadian sectio caesaria adalah dengan melakukan yoga selama kehamilan.

Tujuan: Penelitian ini bertujuan untuk mengetahui apakah ada dampak yoga kehamilan terhadap jenis persalinan pada ibu bersalin.

Metode: Penelitian ini merupakan penelitian ekspriment yang menggunakan design pre ekspreimental dengan menggunakan rancangan intact-group comparation. seluruh ibu hamil TM III yang mengikuti kehamilan yoga 20 responden dan yang tidak mengikuti kehamilan yoga 20 responden dengan teknik purposive sampling. Alat pengumpulan data menggunakan kuesioner. Analisis data menggunakan uji Chi Square dua sample.

Hasil: Jenis persalinan ibu hamil yang melakukan yoga kehamilan sebagian besar dalam kategori normal (spontan) sebanyak 85\% sedangkan sebanyak 15\% dengan melalui tindakan. Jenis persalinan pada ibu hamil yang tidak melakukan yoga kehamilan sebagian besar adalah persalinan normal sebanyak 55\% sedangkan $45 \%$ persalinannya melalui tindakan. Terdapat dampak yoga kehamilan terhadap jenis persalinan dengan dengan nilai p-value $0,038<0,05$ dan $\mathrm{OR}=4,636$ yang berarti bahwa responden yang mengikuti kehamilan yoga 4,6 kali lipat jenis persalinannya adalah normal dibandingkan dengan yang tidak mengikuti yoga kehamilan.
\end{abstract}

Simpulan: Terdapat dampak yoga kehamilan terhadap jenis persalinan pada ibu bersalin di Klinik Pratama Asih Waluyo Jati.

Kata kunci: Yoga Kehamilan, Jenis Persalinan, Ibu Bersalin

\section{ABSTRACT}

Background: Normal delivery is the process of a baby being released from the birth canal spontaneously within 24 hours without causing damage to the mother or baby. Not all mothers can give birth normally so it must be due to 
complications during labor so that labor takes place with the help of vacuum extraction and cesarean section (sc). In Indonesia, the incidence of SC continues to increase every year from 1991 to 2007 , which is $1.3-6.8 \%$. The cause of increased sc childbirth is the presence of medical and non-medical indications. One effort to reduce the incidence of sectio caesaria is to do yoga during pregnancy.

The Purpose: This study aims to determine whether there is an influence of yoga Method: This study is an experimental study using a pre-experimental design using intact-group comparation design. all TM III pregnant women who participated in yoga pregnancy were 20 respondents and those who did not participate in yoga pregnancy were 20 respondents using purposive sampling technique. Data collection tool uses a questionnaire. Data analysis using Chi Square test of two samples

Result: The type of childbirth for pregnant mothers doing pregnancy yoga is mostly in the normal (spontaneous) category as much as $85 \%$ while as many as $15 \%$ through action. The type of delivery in pregnant women who do not do yoga pregnancy is mostly a normal delivery of $55 \%$ while $45 \%$ of deliveries through action. There is the an impact of pregnancy yoga on the type of delivery with a pvalue of $0.038<0.05$ and $\mathrm{OR}=4.636$, which means that respondents who participated in yoga pregnancy 4.6 times the type of childbirth are normal compared to those who did not participate in pregnancy yoga.

Conclusion: there is an impact of pregnancy yoga on the type of childbirth at the maternity mothers at Pratama Asih Waluyo Jati Clinic.

Keyword: Pregnancy Yoga, Type of Delivery, Maternity

\section{PENDAHULUAN}

Semua wanita mengharapkan persalinannya berjalan lancar dan dapat melahirkan bayi dengan sempurna (Salfariani, 2012). Persalinan bisa saja berjalan secara normal, namun tidak jarang proses persalinan mengalami hambatan dan harus dilakukan melalui operasi. Hal ini berarti janin ibu dalam keadaan gawat darurat dan hanya dapat diselamatkan jika persalinan dilakukan dengan jalan operasi (Henderson, 2007).

Persalinan adalah proses membuka dan menipisnya servik dan janin turun ke dalam jalan lahir (Aprillia, 2011). Terdapat beberapa macam proses persalinan berdasarkan cara pengeluarannya yaitu persalinan spontan, persalinan buatan dan persalinan anjuran (Aprillia, 2011).

Persalinan normal adalah persalinan dengan letak belakang kepala yang berlangsung spontan dalam 24 jam yang dibagi menjadi empat kala tanpa menimbulkan kerusakan yang lebih pada anak dan ibu. Persalinan normal sering disebut sebagai persalinan biasa yang artinya kelahiran seorang bayi genap bulan dengan letak belakang kepala melalui jalan lahir alamiah dengan tenaga ibu sendiri secara spontan dalam waktu paling lama 18 jam untuk primigravida dalam kondisi ibu yang tetap sehat dengan kerusakan jalan lahir minimal menjadi maksimal apabila terjadi rupture perinea tingkat II (Crisdiono, 2014). 
Persalinan seksio sesaria adalah persalinan melalui sayatan pada dinding abdomen dan uterus yang diambil masih utuh dengan berat janin $>1000 \mathrm{gr}$ atau umur kehamilan >28 minggu. Keputusan untuk melakukan persalinan seksio sesarea diharapkan dapat menjamin turunnya tingkat morbiditas dan mortalitas, sehingga sumber daya manusia dapat ditingkatkan yang tentunya disertai dengan peningkatan keadaan umum sehingga mampu menerima risiko tindakan seksio sesaria, perawatan setelah operasi dan kembalinya kesehatan secara optimal. Dengan demikian, tidak semua ibu hamil dapat melahirkan secara normal. Sebagian dari mereka ada yang mendapatkan masalah atau kesulitan untuk melakukan persalinan normal atau spontan sehingga harus mengalami persalinan secara abnormal yang salah satunya adalah seksio sesarea dilakukan (Manuaba, 2012).

World Health Organization (WHO) menetapkan standar rata-rata persalinan dengan operasi sesar di sebuah negara adalah sekitar 5-15 persen per 1000 kelahiran di dunia. Menurut WHO, peningkatan persalinan dengan operasi sesar di seluruh negara terjadi semenjak tahun 2007-2008 yaitu 110.000 per kelahiran di seluruh Asia. Di Indonesia sendiri, angka kejadian operasi sesar juga terus meningkat baik di rumah sakit pemerintah maupun di rumah sakit swasta. Menurut Data Survey Demografi dan Kesehatan Indonesia (SDKI) menunjukkan terjadi kecenderungan peningkatan operasi sesar di Indonesia dari tahun 1991 sampai tahun 2007 yaitu 1,3-6,8 persen. Persalinan sesar di kota jauh lebih tinggi dibandingkan di desa yaitu 11 persen dibandingkan 3,9 persen (BPS, 2008).

Di Indonesia angka kejadian section caesaria mengalami peningkatan pada tahun 2000 jumlah ibu bersalin dengan section caesaria 47,22\%, tahun 2001 sebesar 45,19\%, tahun 2002 sebesar 47,13\%, tahun 2003 sebesar 46,87\%, tahun 2004 sebesar 53,2\%,tahun 2005 sebesar 51,59\%, dan tahun 2006 sebesar 53,68\% dan tahun 2007 belum terdapat data yang signifikan, tahun 2009 sebesar sekitar 22,8\% (Karundeng, 2014).

Penyebab peningkatan persalinan section caesaria ini yaitu dengan adanya indikasi medis dan indikasi non medis. Indikasi medis diantaranya adalah persalinan tidak maju, kala II lama, ketuban pecah dini (Rasjidi, 2009). Salah satu upaya untuk menurunkan angka kejadian sectio caesaria adalah dengan melakukan yoga selama kehamilan.

Yoga dalam kehamilan menggabungkan postur-postur khusus dan teknikteknik yang bermanfaat bagi ibu hamil dan membantu menghilangkan ketidaknyamanan yang disebabkan oleh perubahan tubuh selama kehamilan. Yoga adalah cara untuk mempersiapkan persalinan karena teknik latihannya menitikberatkan pada pengendalian otot, teknik pernapasan, relaksasi dan ketenangan pikiran. Teknik relaksasi yang dapat dilakukan dengan cara membayangkan sesuatu yang menyenangkan dapat membuat tubuh menjadi relaks (Stoppard, 2008).

Yoga pada kehamilan memfokuskan kenyamanan serta keamanan dalam berlatih sehingga memberikan banyak manfaat (Krisnandi, 2010). Yoga selama hamil dapat meringankan edema dank ram yang sering terjadi pada bulan terakhir kehamilan, membantu posisi bayi dan pergerakan, meningkatkan system pencernaan dan nafsu makan, meningkatkan energy dan memperlambat 
metabolisme untuk memulihkan ketenangan dan fikus, mengurangi rasa mual, morning sickness dan suasana hati, meredakan ketegangan di sekitar leher Rahim dan jalan lahir yang berfokus pada membuka pintu pelvis untuk mempermudah persalinan, membantu dalam perawatan pasca kelahiran dengan mengembalikan uterus, perut dan dasar panggul, mengurangi ketegangan, cemas dan depresi selama kehamilan maupun pada saat persalinan dan masa nifas, ketidaknyamanan payudara (Stoppard, 2008).

Klinik Pratama Asih Waluyo Jati merupakan salah satu tempat pelayanan kesehatan yang melayani kesehatan ibu dan anak di daerah Bantul Yogyakarta. Di Klinik Pratama Asih Waluyo Jati juga membuka kelas yoga kehamilan, dan berdasarkan wawancara dengan bidan di Klinik Pratama Asih Waluyo Jati didapatkan hasil bahwa ibu hamil yang rajin melakukan yoga mendapatkan proses persalinan yang lebih mudah dan lancar dibandingkan ibu hamil yang tidak melakukan yoga kehamilan.

Berdasarkan uraian diatas, maka peneliti tertarik untuk mengetahui "Dampak Yoga Kehamilan terhadap Jenis Persalinan pada Ibu Bersalin”.

\section{METODE PENELITIAN}

Penelitian ini merupakan penelitian ekspriment yang menggunakan design pre ekspreimental dengan menggunakan rancangan intact-group comparation yaitu pengukuran kelompok kasus dan kelompok kontrol pada sample yang sama dan tidak dipilih secara random (Sugiyono, 2016). Adapun paradigma penelitian dpat digambarkan sebagai berikut:

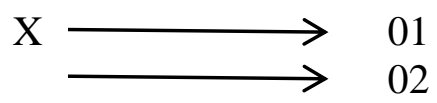

Gambar 4.1 Skema Rancangan Penelitian

Keterangan :
$\mathrm{X} \quad$ : Perlakuan
01 : Jenis persalinan setengah kelompok yang diberi perlakuan
02 : Jenis persalinan setengah kelompok yang tidak diberi perlakuan

Sampel dalam penelitian ini yaitu seluruh ibu hamil TM III yang mengikuti kehamilan yoga 20 responden dan yang tidak mengikuti kehamilan yoga 20 responden sehingga besar sample berjumlah 40 responden. teknik pegambilan sample adalah purposive sampling. Sumber data yang digunakan adalah data primer yang diambil secara langsung dari ibu yang datang pada saat kunjungan postnatal care (PNC) dengan cara membagikan kuesioner. Analisa data dalam penelitian ini menggunakan Uji statistic Chi Square 2 sample. 


\section{HASIL DAN PEMBAHASAN}

Tabel 1 Distribusi Frekuensi Jenis Persalinan pada Kelompok Kasus (Yoga Kehamilan)

\begin{tabular}{ccc}
\hline Jenis Persalinan & Frekuensi (f) & Prosentase $(\%)$ \\
\hline Normal & 17 & 85,0 \\
Tindakan & 3 & 15,0 \\
Total $(\mathrm{n})$ & 20 & 100 \\
\hline
\end{tabular}

Tabel 1 diatas menunjukkan bahwa sebagian besar jenis persalinan pada ibu hamil yang melakukan yoga kehamilan dalam kategori normal (spontan) sebanyak $85 \%$ sedangkan sebanyak $15 \%$ dengan melalui tindakan baik secara sectio caesaria maupun vakum ekstraksi.

Tabel 2 Distribusi Frekuensi Jenis Persalinan pada Kelompok Kontrol (tidak melakukan Yoga Kehamilan)

\begin{tabular}{ccc}
\hline Jenis Persalinan & Frekuensi (f) & Prosentase $(\%)$ \\
\hline Normal & 11 & 55,0 \\
Tindakan & 9 & 45,0 \\
Total $(\mathrm{n})$ & 20 & 100 \\
\hline
\end{tabular}

Tabel 2 diatas menunjukkan bahwa sebagian besar jenis persalinan pada ibu hamil yang tidak melakukan yoga kehamilan adalah persalinan normal sebanyak $55 \%$ sedangkan sebanyak $45 \%$ persalinannya melalui tindakan baik secara section caesaria maupun vakum ekstraksi.

Tabel 3 Dampak Yoga terhadap Jenis Persalinan pada Ibu Bersalin

\begin{tabular}{|c|c|c|c|c|c|c|c|c|}
\hline \multirow{3}{*}{$\begin{array}{c}\text { Yoga } \\
\text { kehamilan }\end{array}$} & \multicolumn{4}{|c|}{ Jenis Persalinan } & & & \multirow{3}{*}{$p$} & \multirow{3}{*}{ OR } \\
\hline & \multicolumn{2}{|c|}{ Spontan } & \multicolumn{2}{|c|}{ Tindakan } & \multicolumn{2}{|c|}{ Total } & & \\
\hline & $\mathrm{n}$ & $\%$ & $\mathrm{n}$ & $\%$ & $\mathrm{n}$ & $\%$ & & \\
\hline Diberikan & 17 & 42,5 & 3 & 7,5 & 20 & 50 & & \\
\hline Tidak diberi & 11 & 27,5 & 9 & 22,5 & 20 & 50 & 0.038 & 4,636 \\
\hline Total & 28 & 70 & 12 & 30 & 40 & 100 & & \\
\hline
\end{tabular}

Berdasarkan tabel 3 diketahui bahwa dari 28 responden yang melahirkan secara spontan 17 responden (42,5\%) diberikan yoga selama kehamilan, sedangkan responden yang tidak diberikan kehamilan yoga mempunyai proporsi melahirkan spontan lebih kecil yaitu sebanyak 11 responden $(27,5 \%)$.

Hasil analisis menggunakan uji Chi-Square dengan $a<0,05$ didapatkan p_value 0,038 artinya $p$ < alpha maka dapat disimpulkan bahwa hipotesis diterima yang artinya ada pengaruh yoga kehamilan terhadap jenis persalinan dengan $\mathrm{OR}=$ 4,636 yang menunjukkan bahwa responden yang mengikuti kehamilan yoga 4,6 kali lipat jenis persalinannya adalah normal dibandingkan dengan yang tidak mengikuti yoga kehamilan. 
Hasil penelitian pada tabel 1 dapat dilihat bahwa sebagian besar jenis persalinan pada ibu hamil yang melakukan yoga kehamilan dalam kategori normal (spontan) sebanyak 85\% sedangkan sebanyak 15\% dengan melalui tindakan baik secara sectio caesaria maupun vakum ekstraksi. Sedangkan hasil penelitian pada tabel 2 dapat dilihat bahwa bahwa sebagian besar jenis persalinan pada ibu hamil yang tidak melakukan yoga kehamilan adalah persalinan normal sebanyak $55 \%$ sedangkan sebanyak $45 \%$ persalinannya melalui tindakan baik secara section caesaria maupun vakum ekstraksi

Jenis persalinan ibu yang mengikuti senam yoga selama kehamilan sebagian besar adalah persalinan normal, Persalinan normal adalah persalinan dengan letak belakang kepala yang berlangsung spontan dalam waktu 24 jam yang dibagi menjadi empat kala tanpa menimbulkan kerusakan yang lebih pada anak dan ibu. Persalinan normal sering disebut sebagai persalinan biasa yang artinya kelahiran seorang bayi genap bulan dengan letak belakang kepala melalui jalan lahir alamiah dengan tenaga ibu sendiri secara spontan dalam waktu paling lama 18 jam untuk primigravida dalam kondisi ibu yang tetap sehat dengan kerusakan jalan lahir minimal menjadi maksimal apabila terjadi rupture perinea tingkat II (Crisdiono, 2014). Keuntungan dari persalinan normal sendiri adalah pemulihan pasca persalinan lebih cepat, cepat bebas bergerak sehingga lebih cepat mengurus bayinya sendiri dan menjalin bounding yang lebih kuat dengan bayi, lebih mudah dalam melakukan IMD sehingga bayi lebih sehat (Cristiane Northup, 2005). Melihat begitu banyaknya manfaat persalinan normal namun tidak semua ibu dapat atau memilih bersalin secara normal, begitupun dengan hasil penelitian bahwa dari 40 responden terdapat 12 responden yang melahirkan dengan tindakan berupa vakum dan section sesarea. Banyak faktor yang menyebabkan seorang ibu bersalin dengan tindakan, salah satunya adalah ibu bersalin yang mengalami penyulit pada saat inpartu maka akan berisiko melahirkan dengan tindakan, persalinan tindakan adalah persalinan yang tidak dapat berjalan normal secara spontan atau tidak berjalan sendiri sehingga persalinan dilakukan dengan alat bantu ( mochtar 1998 dalam Annisa, 2011). Adapun yang menjadi alat bantu dalam persalinan dengan tindakan dapat berupa vakum ekstrasi dan section sesarea. Persalinan dengan bantuan vakum ekstrasi digunakan pada saat ibu merasa letih dan tidak mampu mengejan dengan efektif, selain itu juga digunakan untuk memutar presentasi melintang atau posterior menjadi posisi anterior (Manuaba, 2009). Sedangkan section sesarea dilakukan pada saat ibu memiliki indikasi dilakukannya sc diantaranya ibu memiliki riwayat sc, distosia bahu, dan distress janin. Adapaun persalinan dengan sc adalah persalinan dengan tindakan mengeluarkan janin lewat abdomen dengan cara melakukan insisi pada dinding abdomen dan dinding uterus (Cunningham, 2005). Persalinan dengan section memiliki risiko kematian empat kali lebih besar dibandingkan persalinan normal, darah yang dikeluarkan dua kali lebih banyak dibandingkan persalinan normal, serta kehamila dibatasi minimal 2 tahun setelah operasi (Muhammad, 2009).

Berdasarkan hasil penelitian tabel 3 didapatkan bahwa ada pengaruh yoga kehamilan terhadap jenis persalinan dengan p-value 0,038 dan OR 4,636 yang artinya responden yang mengikuti kehamilan yoga 4,6 kali lipat jenis persalinannya adalah normal dibandingkan dengan yang tidak mengikuti yoga 
kehamilan. Jenis persalinan dipengaruhi oleh beberapa faktor diantaranya tenaga atau kekuatan ibu (power), jalan lahir (passage), janin (passage), psikis wanita (ibu), dan penolong. Ibu yang tidak memiliki kekuatan untuk mengedan, ukuran kepala janin dan posisi janin yang tidak searah dengan jalan lahir, serta kondisi psikologis ibu bersalin yang cemas menyebabkan persalinan berakhir dengan tindakan baik itu vakum maupun section sesarea (Annisa, 2011). Penyulit pada saat persalinan dapat di cegah dengan latihan olahraga dan relaksasi yang mana hal tersebut dapat diperoleh melalui yoga kehamilan Karena yoga merupakan suatu olah tubuh, pikiran dan mental yang sangat membantu ibu hamil dalam melenturkan persendian dan menenangkan pikiran terutama pada ibu hamil trimester III ${ }^{1^{5}}$. Yoga merupakan salah satu cabang olahraga yang sangat baik bagi ibu hamil, yoga kehamilan merupakan modifikasi dari olahraga senam yang disesuaikan gerakannya dengan kondisi ibu hamil. (Indiarti, 2009). Melalui yoga ibu hamil akan rutin bergerak sehingga dapat mempercepat persalinan normal, hal tersebut sesuai dengan teori yang menyatakan bahwa ibu hamil yang sering bergerak selama hamil akan dapat mempengaruhi (mempercepat) proses persalinan (Mahmudah (2010). Yoga kehamilan dapat meningkatkan peluang seorang ibu melahirkan secara normal, hal tersebut dikarenakan latihan yoga secara rutin dapat memberikan manfaat bagi ibu hamil diantaranya tubuh lebih fleksible/lentur, tubuh yang lentur akan mengurangi rasa mudah pegal dan nyeri pada saat menjelang persalinan, selain itu yoga kehamilan juga dapat menjadikan tubuh lebih kuat pada saat mengejan dan mengurangi stress pada saat menjelang persalinan (Aduard De Grave, 2013). Menurut teori disebutkan bahwa latihan yoga kehamilan secara teratur juga dapat meningkatkan kapasitas paru-paru sehingga ibu yang melahirkan tidak akan mudah sesak dan lebih pintar mengolah pernafasananya pada saat kontraksi Rahim (Puji Astuti, 2013.

\section{SIMPULAN DAN SARAN}

\section{Simpulan}

Jenis persalinan ibu hamil yang melakukan yoga kehamilan sebagian besar dalam kategori normal (spontan) sebanyak 85\% sedangkan sebanyak 15\% dengan melalui tindakan baik secara sectio caesaria maupun vakum ekstraksi. Jenis persalinan pada ibu hamil yang tidak melakukan yoga kehamilan sebagian besar adalah persalinan normal sebanyak $55 \%$ sedangkan $45 \%$ persalinannya melalui tindakan baik secara section caesaria maupun vakum ekstraksi. Ada pengaruh yoga kehamilan terhadap jenis persalinan dengan dengan nilai $\mathrm{p}$-value $0,038<0,05$ dan $\mathrm{OR}=4,636$ yang berarti bahwa responden yang mengikuti kehamilan yoga 4,6 kali lipat jenis persalinannya adalah normal dibandingkan dengan yang tidak mengikuti yoga kehamilan.

\section{Saran}

Bagi fasilitas kesehatan di wilayah Yogyakarta dari hasil penelitian ini diharapkan dapat memberikan pelatihan yoga kehamilan pada ibu hamil sehingga tercipta persalinan yang normal dan aman. 


\section{DAFTAR PUSTAKA}

Achadiat, Chrisdiono, M. (2004). Prosedur Tetap Obstetri dan Ginekologi. Jakarta: EGC.

Annisa, S. A. (2011). Faktor-faktor risiko persalinan seksio sesarea di RSUD Dr. Adjidarmo Lebak pada bulan Oktober-Desember 2010. Publikasi Skripsi Sarjana Kedokteran Universitas Islam Negeri Syarif Hidayatullah Jakarta

Aprilia, Y dan Ritchmond, B. (2011). Gentle Birth: Melahirkan Nyaman Tanpa Rasa Sakit. Jakarta: PT Gramedia Widiasarana Indonesia.

Badan Pusat Statistik, BKKBN, Kementrian Kesehatan, Macro Inc, Laporan Survey Demografi dan Kesehatan Indonesia. (2007). BKKBN. Departemen Kesehatan, Macro Calverton Mary Land.

Cunningham, dkk. Obstetri Williams. Edisi 21. Jakarta: EGC; 2006

Grave de Eduard, Gito Utoyo dan Lara Laurena Ananda. (2013). Yoga untuk pasangan suami istri. Jakarta: Be champion penebar swadaya group

Henderson-smart DJ. Lumbiganon P, Festin MR, Ho JJ, Mohammad H, McDonald SJ, et al. (2007). Methodology Oprimising Reproductive and Child Health Outcome by Building Evidence Based Research and Practice in South East Asia (SEA-ORCHID): Study Protocol. BMC Med Res Methodol.

Indiarti M, T. (2009). Panduan lengkap kehamilan, persalinan \& perawatan bayi bahagia menyambut si buah hati. Diglossia Media. Yogyakarta

Karundeng, dkk. (2014). Faktor-Faktor yang Berperan Meningkatnya Angka Kejadian Sectio Caesaria. (diakses 23 September 2019).

Krisnadi, S.R, Anwar, A.D \& Alamsyah, M. (ed). (2012). Obstetri Emergency. Jakarta: Sagung Seto.

Mahmudah. (2010). Pengaruh Persalinan dengan Komplikasi terhadapKemungkinan Terjadinya Baby Bluesdi Kota Semarang. Tesis FK UI.

Manuaba (2009). Buku ajarpatologi obstetri untuk mahasiswa kebidanan.Jakarta: EGC

Manuaba I. (2012). Ilmu Kebidanan, Penyakit Kandungan, dan KB. Kajarta: EGC.

Northrup, Christianne. (2005). Women's bodies,women wisdom, bantam dell. $3^{\text {rd }}$ Edition New York

Rasjidi, Imam. (2009). Manual Seksio Sesarea \& Laparotomi Kelainan Adneksa. Jakarta: CV Sagung Seto.

Salfariani I, Nasution S-S. (2012). Caesaria Tanpa Indikasi Medis di RSU Bunda Thamrin Medan. Jurnal Keperawatan Klin.

Sindhu, Pujiastuti. (2014). Panduan Lengkap Yoga untuk Hidup Sehat dan Seimbang. Bandung: PT Mizan Pustaka

Stoppard M. (2008). Buku Ajar Asuhan Kebidanan. Jakarta: EGC.

Sugiyono. (2016). MetodePenelitian Kuantitatif, Kualitatif dan R\&D. Bandung: PT Alfabet 